\title{
ANALISIS PENGARUH KOMPETENSI DAN IKLIM ORGAISASI TERHADAP KINERJA PEGAWAI PADA UNIVESITAS METHODIST INDONESIA MEDAN
}

\author{
Siti Normi ${ }^{1}$, Sitti Raha Agoes Salim ${ }^{2}$, Khaira Amalia F 3 \\ ${ }^{1}$ Alumni Magister Ilmu Manajemen SPs USU \\ ${ }^{2}$ Dosen Magister Ilmu Manajemen SPs USU \\ ${ }^{3}$ Dosen Magister Ilmu Manajememn SPs USU
}

\begin{abstract}
The performance of employees working at a university is one of the aspects of organization which is very much influenced by the competency and climate of organization. The importance of improving the performance in the work environment at the university is directly related to the students' interest. Competency is an individual capacity to do various tasks of a work. The climate of organization is an atmosphere of organization created by several components that form a value of policy whose implementations is in accordance with the interest of working group. In general, competency has 2 ( two) main indicators namely knowledge and skill while the climate of organizations has 3 ( three) main indicators such as policy of organization, job description and compensation/reward system. The purpose of this survey with quantitative approach was to quantitatively explain the influence of competency and climate organizational on the performance of employees of University Methodist Indonesia Medan. The population of this study was all of the 52 employees still registered until 2011 and all of them were selected to be the samples for this study through total sampling technique. The data for this study were obtained through questionnaire-based interviews and documentation studies. The data obtained were analyzed through multiple linear regression test to inferentially test the influence of independent variables such as competency and climate of organizational on the dependent variable (employees' performance). The result of this study showed that the competency conditional of the employees' of University Methodist Indonesia Medan which was majorly good $(73,1 \%)$ had significant influence of the performance of the employees. The condition of climate of organization of University Methodist Indonesia Medan which was majorly good (63,5\%) had significant influence on the performance of employees. The competency and climate of organization had significant influence on the performance of employees. The management of University Methodist Indonesia Medan is suggested to more impore the competency either through seminar, course, and related trainings that the performance of their employees can be more improved.
\end{abstract}

Keyword : Competency, Climate of Organization, Employee's Performance. 


\section{A. PENDAHULUAN}

\section{Latar Belakang}

Peguruan tinggi memiliki andil yang sangat berperan dalam seluruh proses penciptaan sumber daya manusia.

Untuk mewujudkan perguruan tinggi yang sehat dibutuhkan dukungan dari semua unsur pemangku jabatan (stakeholders), yaitu : pembuat dan pengawas kebijakan, pegawai sebagai pelaksana kebijakan, masyarakat perguruan tinggi dan masyarakat umum sector produktif, asosiasi prfesi, lembaga swadaya masyarakat, alumni perguruan tinggi, media masa, serta kelompo masyarakat lainnya.

Data yang diperoleh dai Direktorat Jendral Penddikan Tinggi sampai dengan Agustus 2007 menyatakan ada 2320 Perguruan Tinggi di seluruh Indonesia yang terbagi menjadi 2238 PTS dan 82 PTN. Data tersebut menunjukkan bahwa ada dua unsur penting penyedia jasa yang menjadi ujung tombak bagi industri jasa pendidikan peguruan tinggi untuk dapat memberikan pelayanan jasa yang prima. Unsur pertama adalah tenaga edukasi dan kedua adalah tenaga admnistrasi. Tanpa peningkatan kualitas tenaga edukasi sulit tentunya bagi universitas untuk bersaing.

Sebagai unsur kedua dalam penyedia jasa, pegawai atau tenaga administrasi memegang peranan kunci dalam proses pelayanan pada mahasiswa. Misalnya proses pengurusan Kartu Tanda Mahasiswa (KTM), Kartu Rencana Studi (KRS), Kartu Hasil Studi (KHS), dan proses-proses lain yang berhubungan dengan administrasi

perkuliahan. Kualitas layanan (sevice quality) dari tenaga administrasi akan sangat mempengaruhi kepuasan dari mahasiswa. Layanan yang baik akan meningkatkan kepuasan dan mempengaruhi tingkat competitive advantage perguruan tinggi untuk dapat memenangkan persaingan.

Kompetensi menurut Spencer (2001) dapat diuraikan kedalam 3 (tiga) bagian penting, yakni pengetahuan, ketrampilan, dan kemampuan yang sangat diperlukan dalam mendukung suatu kinerja. Ketiga jenis kompetensi ini merupakan kompetensi superficial (kompetensi dasar) dari seseorang untuk menunjukkan kinerja yang efektif dalam pekerjaan.

Iklim organisasi merupakan faktor yang tidak dapat diabaikan dalam suatu system pengelolaan perguruann tinggi, sebab iklim organisasi merupakan kondisi lingungan kerja yang dapat mempengaruhi kinerja pegawai. Pemanfaatan sumber daya mnusi yang efektif dan terarag menjadi kunci peningkatan kinerja karyawan ang salah satunya dengan memberikan lingkungan perusahaan iklim organisasi yang menguntungkan. Oleh sebab itu, adanya iklim organisasi yang tepat akan mempengaruhi kinerja karyawan.

Pemahaman tentang iklim organisasi tersebut diatas tidak berbeda jauh dari pendaoat Handoko (2004:19), bahwa iklim organisasi merupakan suatu suasana 
organisasi yang diciptakan beberapa kompponen yang membentuk nilai kebijakan, yang pelaksanaannya sesuai dengan kelompok kerja. Komponenkomponen yang membentuk suasana ini meliputi : praktik pengambilan keputusan yang lebih partisipatif dan berpola kelompok, adanya arus komunikasi yang mengalir ke seluruh jenjang organisasi, terciptanya kondisi kerja sehingga mendorong para pegawai untuk bekerja lebih giat, adanya penghargaan yang penuh terhadpa sumber daya manusia sebagai modal dasar organisasi, dan adanya peyediaan teknologi ssuai dengan kebutuhan untuk melaksanakan tugas pekerjaan.

Dari pengertian diatas, terlihat ada 3 (tiga) komponen utama iklim organisasi, yakni kebijakan organisasi, struktur organisasi (pembagian tugas), dan system penghargaan (kompensasi) yang mutlak untuk mencapai iklim organisasi yang baik sebagai perwujudan dari kepribadian organisasi secara keseluruhan. Dengan kata lain, iklim organisasi merupakan budaya, tradisi, dan metode tindakan yang dianut oleh organisasi.

Dari pengertian iklim organisasi diatas, penulis menuliskan pengertian ilim organisasi dalam penelitian ini sebagai kualitas lingkungan yang secara terusmenerus meningkat sebagai mana yang dirasakan oleh anggota-anggotanya, mempengaruhi perilaku dan dapat digambarkan menurut seperangkat nilai-nilai karakteristik tertentu dari organisasi. Dengan demikian, pentingnya iklim organisasi adalah karena iklim orgganisasi merupakan suatu system yang mengaitkan konteks organisasi dengan konsep-konsep, perasaan-perasaan, dan harapan-harapan anggota organisasi dan membantu menjelaskan perilaku anggota organisasi. Terjadinaya perubahan pada subsistem akan menimbulkan perubahan pada subsistem lainnya. Dengan mengetahui sesuatu tentang iklim suatu organisasi, kita dapat memahami lebih baik apa yang mendorong anggota organisasi untuk bersikap dengan cara-cara tertentu (Pace, 2000).

Dari berbagai penjelasan tersebut di atas jelas bahwa selain kompetensi, iklim organisasi sangat menentukan pencapaian kinerja, bedanya adalah kompetensi sebagai faktor internal sedangkan iklim organisasi adalah faktor eksternal.

Mengacu kepada pentingnya peningkatan kinerja di lingkungan kerja perguran tinggi dengan berbagai tugas yang berkaitan langsung dengan kepentingan mahasiswa, penulis membatasi cangkupan dalam penelitian ini ke dalam 3 (tiga) bagian penting, yakni cangkupan standard kerja, efektivitas, dan efisiensi. Hal ini sesuai dengan pendapat Mathis dan Jackson (2002), bahwa kinerja seberapa banyak mereka memberikan kontribusi kepada organisasi yang antara lain meliputi kuantitas keluaran, kualitas keluaran, jangka waktu keluaran, kehadiran di tempat kerja, dan sikap kooperatif. Cakupan standard kerja tersebut di atas sebenarnya sudah mencangkup kuantitas dan kualitas kerja.

Hasil pra-penelitian Yang dilakukan di Universitas Methodist Indonesia Medan tahun 2011 menunjukkan bahwa terjadi fluktuasi dalam pendaftaran mahasiswa di semua Fakultas Komputer, Fakultas Sastra, Fakultas Ilmu Komputer, Fakultas Pertanian, dan Fakultas Kedokteran Universitas 
Methodist Indonesian Medan. Fluktuasi jumlah pendaftar dan mahasiswa yang diterima secara lansung juga mempengaruhi volume kerja pegawai, khususnya yang berhubungan dengan kepentingan administrasi mahasiswa, pendataaan identitas serta jumlah per semester dan per tahun ajaran, pengurusan KRS dan KHS bagi mahasiswa yang masih mengambil mata kuliah, penerbitan transkrip nilai bagi mahasiswa yang telah menyelesaikan mata kuliah, penyiapan bahan-bahan perkuliahan dan seminar, praktek, penetapan jumlah mahasiswayang akan di wisuda, dan lain sebagainya.

Berdasarkan pengamatan, ada beberapa fenomena yang menyebabkan kinerja pegawau Universitas Methodist Indonesia Medan kurang optimal baik secara individu maupun secara kolektif. Misalnya, adanya kebiasaan-kebiasaan buruk seperti menunda-nunda pekerjaan meskipun pegawai yang bersangkutan memiliki pengetahuan dan ketrampilan kerja yang baik, cakap, berbakat, dan kompeten dalam bidang pekerjaannya. Hal ini umumnya terjadi karena kurangnya pemahaman pegawai tentang pentingnya kerjasama kelompok, koordinasi dan diskusi kelompok, persepsi yang salah tentang pengukuran kinerja individu dan sikap ego yang berlebihan.

Meskipun tidak semua pegawai memiliki kebiasaan buruk tersebut, namun efeknya sangat menghambat peningkatan kinerja secara kolektif. Kondisi ini mengindikasiakan pentingnya peningkatan kompetensi khususnya pengetahuan/pemahaman tentang perilaku dan etika kerja dalam tim.

\section{Tujuan dan Manfaat Penelitian}

\section{Tujuan Penelitian}

Untuk menganalasis pengaruh kompetensi dan iklim organisasi terhadap kinerja pengawai pada Universitas Methodist Indonesia Medan.

\section{Manfaat Penelitian}

Hasil penelitian ini dapat dijadikan sebagai bahan studi lanjutan yang relevan dan bahan kajian ke arah pengembangan konsep-konsep pengembangan kinerja pegawai yang mendekati pertimbanganpertimbangan konstektual dan konseptual serta kultur yang berkembang pada dunia pendidikan dewasa ini.

Memberikan sumbangan pemikiran terhadap pengembangan manajemen pendidikan, bagi para pelaku perusahhan termasuk di dalmanya pegawai, penyelenggara pendidikan, mahasiswa, alumni, dan instansi lain sebagai penerima layanan pendidikan.

Mengembangkan ilmu pengetahuan mengenai pengembangan sumber daya manusia diperguruan tinggi khususnya pegawai.

Penelitian ini diharapkan
berguna untuk membantu dalam
pengembangan kebijakakan dalam
daya manusia khusunya implementasi
pengembangan pegawaai di institusi
pendidikan.




\section{B. TINJAUAN PUSTAKA}

\section{Kompetensi}

Kompetensi menurut Spencer \& Spencer dalan Palan (2007) adalah sebagai karakteristik dasar yang dimiliki oleh seorang individu yang berhubungan secara kausal dalam memenuhi kritia yang diperlukan dalam menduduki suatu jabaatan.

\section{Iklim Organisasi}

Menurut Tagiuri dan Litwin dalam Wirawan (2007), iklim organisasi merupakan kualitas lingkungan internal organisasi yang secara relative rerus berlangsung, dialami oleh anggota organisasi, mempengaruhi perilaku mereka, dan dapat dilukiskan dalam pengertian satu set kararkteristik atau sifat organisasi.

\section{Kinerja}

Permana (2005) , menyebutkan kinerja adalah penampilan hasil karya personel baik kuantitas maupun kualitas dalam suatu organisasi. Kinerja dapat merupakan penampilan individu atau kelompok kerja personel, penampilan hasil karya maupun struktur, tetapi juga pada keseluruhan jajaran personel dalam organisasi.

\section{Kerangka Konseptual}

Pengaruh kompetensi terhadap kinerja dalam penelitian ini menggunakan teori kompetensi Spencer (2001) yang menyatakn bahwa kompetensi terdiri dari indicator pengetahuam dan kerampilan. Smith da Millership (2007) juga menyatakan bahwa kompetensi merupakan kombinasi pengetahuan dan ketrampilan yang relevan dengan pekerjaan.

Kompetensi adalah kapasitas untuk menangani suatu pekerjaan atau tugas berdasarkan suatu standar yang telah ditetapkan. Disamping itu, kompetensi menunjukkan ketrampilan atau pengetahuan yang dicirikan oleh profesionalisme dalam suatu bidang tertentu sebagai suatu yang terpenting. Kompetensi mempengaruhi kinerja seseorang, yang berarti kompetensi merupakan kombinasi dari pengetahuan dan ketrampilan yang mempengaruhi kinerja.

Hersey dalam Wirawan (2007) mengemukakan bahwa konsep iklim organisasi pertama kali dikemukakan oleh Litwin dan Stringer, bahwa iklim organisasi adalh suatu suasana organisasi yang diciptakan beberapa komponen, seperti kebijakan organisasi yang berpola, pembagian tugas yang jelas sesuai hirarki organisasi dan sistem penggajian (kompensasi) yang terjamin. Iklim organisasi juga mendorong dan merangsang para pegwai untuk bekerja giat sehingga memungkinka bawahan meningkatkan kinerjanya.

Menurut Hersey dalam Wirawan (2007), kinerja merupakan integrasi dari banyak faktor, antara lain : pengetahuan, sumber daya bukan manusia, posisi strategis, dan struktur atau iklim organisasi. Dengan kata lain, kompetensi (pengetahuan) dan struktur atau iklim organisasi berpengaruh terhadap kinerja pegawai.

Menurut Dalen dalam MangkuNegara (2000), bahwa kinerja adalah akumulasi dari tiga elemen yang sangat berkaitan, yaitu upaya mencapai standar kerja yang ditetapkan, efektifitas, dan 
efisiensi disamping sifat-sifat keadaan eksternal lainnya. Standar kerja adalah hasil perbandingan antara realisasi volume kerja yang dicapai dengan rencana kerja yang ditetapkan, maka dapat disusun sebuah kerangka konseptual dalam penelitian ini sebagai berikut :

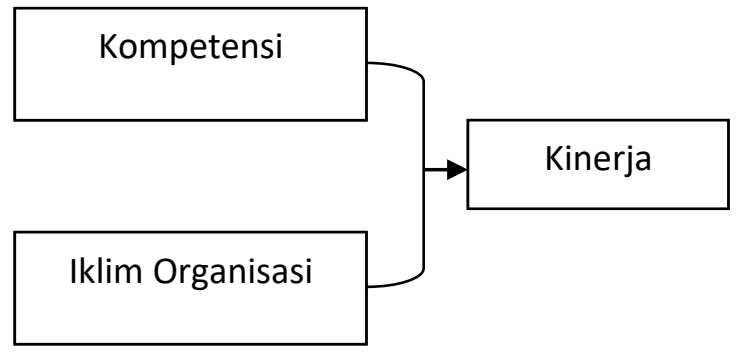

Gambar 1. Kerangka Konseptual

\section{Hipotesis}

$\mathrm{H}_{1}$ : Kompetensi pegawai berpengaruh terhadap kinerja pegawai di Universitas Methodist Indonesia Medan.

$\mathrm{H}_{2}$ : Iklim organisasi berpengaruh terhadap kinerja pegawai di Universitas Methodist Indonesia Medan.

$\mathrm{H}_{3}$ : Terdapat pengaruh kompetensi dan iklim organisasi terhadap kinerja pegawai di Universitas Methodist Indonesia Medan.

\section{METODE PENELITIAN}

\section{Defenisi Operasioanl}

Berdasarkan perumusan masalah, kerangka konseptual dan hipotesis yang diajukan, maka variabel-variabel dalam penelitian ini untuk hipotesis pertama diidentifikasikan sebagai berikut :

Variabel bebas (independent variable) adalah variabel yang mempengaruhi atau yang menjadi seban timbulnya perubahan pada variable terikat, yaitu :
Kompetensi $\left(\mathrm{X}_{1}\right)$, adalah bahwa iklim organisasi merupakan kapasitas individu untuk mengerjakan berbagai tugas dalam suatu pekerjaan (Robbins dalam Dinar, 2007). Kompetensi adalah kemampuan, kecakapan, keadaan, dan wewenang. Iklim organisasi $\left(\mathrm{X}_{2}\right)$, adalah bahwa iklim organisasi merupakan suatu suasana organisasi yang diciptakan beberapa komponen ang membentuk kebijakan, yang pelaksanaannya sesuai dengan kelompok kerja.

Variabel terikat (dependent variable) adalah variabel yang dipengaruhi atau menjadi akibat karena adanya perbahan dari variabel bebas, yaitu Kinerja Pegawai (Y), adalah salah satu tolak ukur untk melihat suatu kesuksesan dalam melaksanakan suatu pekerjaan.

\section{Metode Analisis Data}

Metode analisis data yang digunakan dalam penelitian ini dengan menggunakan regresi linear berganda (Multiple Regression), dengan model sebagai berikut :

$$
\mathbf{Y}=\mathbf{a}+\mathrm{b}_{1} \mathrm{X}_{1}+\mathrm{b}_{2} \mathrm{X}_{2}+\mathrm{e}
$$

Uji Hipotesis :
a. Uji Serempak (Uji F)
b. Uji Parsial (Uji t)
c. Koefisien Determinasi $\left(\mathrm{R}^{2}\right)$ 


\section{ANALISIS DAN PEMBAHASAN}

\section{Model Regresi Linear Berganda}

Berdasarkan koefisien pengaruh masing-masing variable bebas $X_{1}$ dan $X_{2}$, persamaan regresi linear berganda dapat dituliskan sebagai berikut ;

$Y=-1.685+0.496 X_{1}+0.537 X_{2}+3.256$

Persamaan regresi ini mengindikasikan bahwa jika faktor lain diasumsikakn tetap, maka setiap peningkatan kompetensi 1 satuan, akan meningkatkan kinerja pegawai sebesar 0.496 satuan, dan setiap peningkatan iklim organisasi 1 satuan, akan meningkatkan kinerja pegwai sebesar 0.537 satuan.

\section{Koefisien Determinasi $\left(\mathrm{R}^{2}\right)$}

Besarnya pengaruh variabel bebas terhadap variabel terikat adalah denngan menggunakan uji koefisien determinasi $\left(\mathrm{R}^{2}\right)$ berikut :

Tabel 1. Hasil Uji Determinasi

\begin{tabular}{ccccc}
\hline Model & $\mathbf{R}$ & $\begin{array}{c}\mathbf{R} \\
\text { Square }\end{array}$ & $\begin{array}{c}\text { Adjusted } \\
\mathbf{R} \\
\text { Square }\end{array}$ & $\begin{array}{c}\text { Std. } \\
\text { Error of } \\
\text { the } \\
\text { Estimate }\end{array}$ \\
\hline 1 & $.892(\mathrm{a})$ & .795 & .787 & 2.81088 \\
\hline
\end{tabular}

Sumber : Hasil Penelitian, 2014 (data dioalah)

Pada Tabel 1 memperlihatkan bahwa R-square $=0.795$, dengan demikian besar pengaruh serentak dari variabel bebas $\mathrm{X}_{1}$ dan $\mathrm{X}_{2}$ terhadap variabel terikat $\mathrm{Y}$ (kinerja pegawai $=79.5 \%$. Angka ini menunjukkan bahwa $79.5 \%$ kinerja pegawai dapat diasumsikan oleh variabel bebas $\mathrm{X}_{1}$ dan $\mathrm{X}_{2}$, sedangakan selebihaya $20.5 \%$ lainnya diasumsikan oleh faktor-faktor lain yang tidak diteliti.

\section{Uji F (Serempak)}

Tabel 2. Hasil Uji F Serempak

\begin{tabular}{|c|c|c|c|c|c|}
\hline \multicolumn{2}{|c|}{ Model } & $\begin{array}{c}\text { Sum of } \\
\text { Squares }\end{array}$ & Dr & $\begin{array}{c}\text { Mean } \\
\text { Square }\end{array}$ & $\mathbf{F}_{\text {-hitunng }}$ \\
\hline \multirow{3}{*}{1} & $\begin{array}{l}\text { Regre } \\
\text { ssion }\end{array}$ & 1504.924 & 2 & 752.462 & 95.235 \\
\hline & $\begin{array}{c}\text { Resid } \\
\text { ual }\end{array}$ & 387.153 & 49 & 7.901 & \\
\hline & Total & 1892.077 & 51 & & \\
\hline
\end{tabular}

Sumber : Hasil Penelitian, 2014 (data diolah)

Pada Tabel 2 memperlihatkan bahwa nilai $\mathrm{F}^{-}{ }_{\text {hitung }}=95.235$ dengan signifikasi $(\mathrm{p}$ value $)=0.000$. Jika dibandingkan dengan $\mathrm{F}_{\text {tabel }}=3.15$ (yang diperoleh dari $\mathrm{N}=52$ atau $\mathrm{df}=50)$ dan sig- $\bullet(0.05)$. Hasil analisis ini memenuhi persyaratan uji pengaruh, dimana jika $\mathrm{F}_{\text {-hitung }}>\mathrm{F}_{\text {-tabel }}$ maka Ho ditolak, dengan demikian dapat disimpulkan bahwa kedua variabel bebas $\mathrm{X}_{1}$ (kompetensi) dan $\mathrm{X}_{2}$ (iklim organisasi) memiliki penaruh signifikan terhadap variabel terikat Y (kinerja pegawai). 
Uji t (Parsial)

Tabel 3. Hasil Uji t Secara Parsial

\begin{tabular}{|c|c|c|c|c|c|c|}
\hline & \multirow[t]{2}{*}{ Model } & \multicolumn{2}{|c|}{$\begin{array}{c}\text { Unstandard } \\
\text { ized } \\
\text { Coefficients }\end{array}$} & $\begin{array}{c}\text { Standard } \\
\text { ized } \\
\text { Coefficie } \\
\text { nts }\end{array}$ & \multirow[t]{2}{*}{$\mathbf{t}$} & \multirow{2}{*}{$\begin{array}{l}\text { Si } \\
\text { g. }\end{array}$} \\
\hline & & B & $\begin{array}{l}\text { Std. } \\
\text { Erro } \\
\mathbf{r}\end{array}$ & Beta & & \\
\hline \multirow[t]{3}{*}{1} & $\begin{array}{c}\text { (Consta } \\
\mathrm{nt})\end{array}$ & $\begin{array}{c}- \\
1.68 \\
5 \\
\end{array}$ & 3.258 & & $\begin{array}{l}- \\
.51 \\
7\end{array}$ & $\begin{array}{c}.60 \\
7\end{array}$ \\
\hline & $\begin{array}{c}\text { Kompet } \\
\text { ensi }\end{array}$ & .496 & .096 & .462. & $\begin{array}{l}5.1 \\
46 \\
\end{array}$ & $\begin{array}{c}.00 \\
0 \\
\end{array}$ \\
\hline & $\begin{array}{c}\text { Iklim } \\
\text { Organis } \\
\text { asi }\end{array}$ & .537 & .095 & .507 & $\begin{array}{l}5.6 \\
59\end{array}$ & $\begin{array}{c}.00 \\
0\end{array}$ \\
\hline
\end{tabular}

Sumber : Hasil Penelitian, 2014 (data diolah)

Pada table 3, nilai-nilai ${ }^{\mathrm{t}}{ }$ hitung $\mathrm{X}_{1}=5.146$ dengan signifikasi ( $\mathrm{p}$ value $)=0.000$. Jika dibandingka dengan $\mathrm{t}^{-}{ }_{\text {tabel }}=1.68$ (yang diperoleh dari $\mathrm{N}=52$ atau df = 50) dan sig- $\bullet=0.05$, dapat disimpulkan bahwa

${ }^{\mathrm{t}}{ }^{\text {hitung }}(5.146)>\mathrm{t}^{-}{ }_{\text {tabel }}=1.68 \mathrm{dan}$ p-value $(0.000)<$ sig-• $(0.05)$. Hasil analisis ini memenuhi persyaratan uji pengaruh,

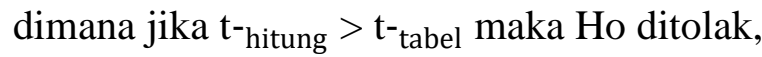
dengan demikian dapat disimpulkan bahwa variabel bebas $\mathrm{X}_{1}$ (kompetensi) memiliki pengaruh signifikan terhadap variabel terikat Y (kinerja pegawai).

Nilai t-hitung $\mathrm{X}_{2}=6.569$ dengan signifikasi $(\mathrm{p}$-value $)=0.000$ Jika dibandingakn dengan $\mathrm{t}_{\text {tabel }}=1.68$ (yang diperoleh dari $\mathrm{N}=52$ atau $\mathrm{df}=50$ ) dan sig- $\bullet=0.05$, dapat disimpulkan bahwa ${ }^{\mathrm{t}}{ }^{\text {hitung }} \mathrm{X}_{2}(5.659)>\mathrm{t}^{\mathrm{t}}{ }_{\text {tabel }}=1.68$ dan p-value $(0.000)<$ sig-• $(0.05)$. Hasil analisis ini memenuhi persyaratan uji pengaruh, dimana jika $\mathrm{t}^{-}$hitung $>\mathrm{t}^{-}$tabel maka $\mathrm{Ho}$ ditolak, dengan demikian dapat disimplkan bahwa variabel bebas $\mathrm{X}_{2}$ (iklim organisasi) memiliki pengaruh signifikan terhadap variabel terikat Y (kinerja pegawai).

\section{PEMBAHASAN}

\section{Kompetensi Pegawai Berpengaruh Terhadap Kinerja Pegawai di Universitas Methodist Indonesia Medan}

Hasil nalisis deskriptif menunjukkan bahwa kompetensi pegawai universitas Methodist Indonesia Medan adalah mayaritas berkategori baik sebesar $73.1 \%$. Bila dilihat dari dimensi, pengetahuan danketrampilan, responden dominan menyatakan setuju untuk pernyataaan pengetahuan menningkatkan kompetensi pegawai $(82.7 \%)$.

Dari 5 (lima) peryataan ketrampilan yang paling dominan adlah jawaban setuju. Dimana pernyataan no. 7 (tujuh) tentang ketrampilan merupakan kemampuan mengaplikasikan pengetahuan sebanyak 59.6\%. Maka apabila rata-rata kedua indikasi ini diperbandingkan, diketahui bahwa kompetensi pengetahuan (69.21\%) lebih dominan dari kompetensi ketrampilan $(51.16 \%)$.

Berdasarkan hasil temuan penelitian dan teori terkait tersebut diatas, peneliti menyebutkan bahwa tidak ada penyimpangan antara praktek dengan teori. Dimana hasil peneliti ini menggambarkan secara jelas kondisi yang sebenarnya.

\section{Iklim Organisasi Berpengaruh Terhadap Kinerja Pegawai di Universitas Methodist Indonesia Medan}


Hasil analisis deskriptif memperlihatkan bahwa kondisi iklim organisasi pegawai Universitas Methodist Indonesia Medan adalah mayoritas baik (63.5\%). Hal ini digambarkan dengan hasil responden yang mayoritas menjawab setuju $(86.5 \%)$ dari ke-5 pertanyaan tentang kebijakan organisasi.

Sedangkan dari ke-3 pernyataan pembagian tugas yang paling dominan adalah jawaban setuju. Dimana pernyataan no. 18 tentang pemberian tugas adalah sesuai dengan kompetensi sebanyak 75.0\% . Berdasarkan skor ke-3 pernyataan tentang system kompensasi yang paling dominan adalah jawaban setuju terhadap pernyataan no. 20, yakni kepuasan pegawai terhadap system kompensasi (55.8\%).

Jika skor rata-rata ke-3 indikator iklim organisasi ini diperbandingka diketahui bahwa pembagian tugas $(72.46 \%)$ lebih dominan dari kebijakan organisasi (70.32\%), dan sistem kompensasi (42.93\%). Maka apabila skor rata-rata kedua indikator kompetensi ini diperbandingkan, diketahui bahwa kompetensi pengetahuan (69.21\%) lebih dominan dari kompetensi ketrampilan $(51.16 \%)$

Hasil uji analisis inferensial juga memperlihatkan adanya pengaruh signifikan dari iklim organisasi terhadap kinerja dengan nilai signifikansi sebesar 0.00 atau lebih kecil dari sig-• (0.05). Signifikansi positif ini mengindikasikan bahwa semakin baik iklim organisasi pegawai semakin besar pula peluang peningkatan kinerja pegawai. Dengan demikian, ada hubunga linear positif antara iklim organisasi pegawai dengan kinerja yang dicapai pegawai. Dengan kata lain, semakin linear hubungannya, semakin signifikan pula pengaruhnya.

Hasil penelitian ini sesuai dengan hasil penelitian terdahulu oleh Risetiawan (2002:89) dengan judul penelitian Pengaruh Iklim Organissi dan Motivasi Terhadap Kinerja Karyawan Perusahaan Daerah Kabupaten Blora.

Hail ini sesuai dengan pendapat Hersey (1995), yang menyatakan bahwa iklim organisasi adalah suatu suasana organisasi yang diciptakan beberapa komponen, seperti kebijaka komponen yang terpola, pembagian tugas yang jelas sesuai dengan hirarki organisasi dan system penggajian (kompensasi) yang terjamin. Iklim organisasi juga mendorong da meragsang para pegawai untuk bekerja giat sehingga memungkinkan bawahan meningkatkan kinerjanya.

Berdasarkan hasil temuan enelitian dan teori terkait tersebut diatas, peneliti menyimpulkan bahwa tidak ada penyimpangan antara praktek dan teori. Dimana hasil penelitian ini menggambarkan secara jelas kondisi yang sebenarnya.

\section{Terdapat Pengaruh Kopetensi dan Iklim Organisasi Terhadap Kinerja Pegawai di Universitas Methodist Indonesia Medan}

Hasil analisis inferensial membuktikan bahwa kompetensi dan iklim organisasi berpengaruh signifikan terhadap kinerja pegawai dan berdasarkan uji determinasi $\mathrm{R}^{2}$ diketahui bahwa variabel kompetensi dan iklim organisasi berpengaruh signifikan terhadap kinerja pegawai dan besarnya pengaruh adalah sebesar $79.5 \%$. Hal ini mengindikasikan bahwa kompetensi iklim organisasi adalah 
dua variabel sumber daya manusia yang tepat dikombinasikan untuk meningkatkan kinerja pegawai. Hasil yang sama juga diperlihatkan oleh analisis inferensial, dimana terbukti bahwa kompetensi berpengaruh signifikan terhadap kinerja pegawai dengan signifikan sebesar 0.00 atau lebih kecil dari sig-• (0.05). Signifikansi posotif ini mengindikasikan bahwa semakin kompetensi pegawai semakin baik pula kinerja pegawai. Dengan demikian, ada hubungan linear positif antara kompetensi pegawai dengan kinerja yang dicapai pegawai. Dengan kata lain, semakin linear hubungannya semakin signifikan pula pengaruhnya. Hal ini sesuai dengan pendapat Sujiono (2006), bahwa linieritas berhubungan dengan keberartian (signifikansi).

Hasil penelitian serupa yang dilakukan oleh Sambas (2008 : 82) Sekolah Pascasarjana Univsitas Sumatera Utara Medan tentang Pengaruh Kompetensi dan Iklim Kerja Terhadap Kinerja Staf di Unit Penunjang Medik rumah Sakit Umum Pusat H. Adam Malik Medan. Dimana analisis data yang dilakukan membuktikan bahwa seluruh variabel kompetensi (pendidikan formal, pengetahuan, tingkat penguasaan tugas, ketampilan teknis, disiplim kerja); dan iklim kerja (kompensasi, kerjasama tim, kesesuaian kerja, pembagian tugas dan, kebijakan organisasi) berpengaruh terhadap kierja koresponden dengan nilai sig-p lebih kecil dari sig-• (0.05). Dimana variabel (iklim kerja) kompensasi mempunyai pengaruh yang paling kuat dibandingkan dengan variabel lainnya.
Demikian halnya dengan hasil penelitiian Effendy (2006 : 91) Program Manajemen Fakultas Ekonomi Universitas Lampung tentang Pengaruh Kompetensi Terhadap Kinerja Karyawan Kantor Pelayanan Pajak Metro (Studi Kasus pada Kantor Pelayanan Pajak Metro), membuktikan bahwa variabel kompetensi memeliki pengaruh signifikan terhadap kinerja karyawan dengan sig-p lebih kecil dari 0.05 pada taraf kepercayaan $95 \%$.

Hasil penelitian serupa dari Parluhutan (2009 : 84), Program Pascasarjana Univeristas Sumatera Utara berjudul Pengaruh Kompetensi Terhadap Kinerja Petugas Promosi Kesehatan Puskesmas di Wilayah Kerja Pematangsiantar tahun 2009 membuktikan bahwa ada pengaruh signifikan dari pengetahuan (pengetahuan, ketrampilan, dan sikap) terhadap kinerja pegawai kesehatan di Pematangsiantar 2008 dengan nilai sig-p lebih kecil dari 0.05 pada tingkat kepercayaan $95 \%$.

Hal ini sesuai dengan pendapat Wirawan (2007), bahwa faktor-faktor yang mempengaruhi kinerja adalah 1). Personal factor termasuk kompetensi dan 2). Situational factor termasuk iklim organisasi. Lebih lanjut dijelaskan bahwa iklim organisasi sebagai koleksi dan pola lingkungan yang menentukan munculnya motivasi serta berfokus pada persepsipersepsi yang masuk akal atau dapat diniai, sehingga berpengaruh langsung terhadap kinerja anggota organisasi. Tagiuri dan Litwin (2007 : 31), mengatakan bahwa iklim organisasi merupakan kualitas lingkungan internal organisasi yang secara relatif terus berlangsung, dialami oleh anggota 
organisasi dan Kelneer dalam Lila (2002) menyebutkan ada beberapa iklim organisasi yang berperan meningkatkan kinerja, yakni :

1. Flexibility conformity, yakni kondisi organisasi yang untk mmberikan keluasan bertindak bagi karyawan serta melakukan penyesuaian diri terhadap tugas-tugas yang diberikan. Hal ini berkaitan dengan aturan yang ditetapkan organisasi, kebijakan dan prosedur yang ada. Penerimaan terhadap ide-ide yang baru merupakan nilai pendukug didalam mengembangkan iklim organisasi yang kondusif demi tercapainya tujuan organisasi.

2. Responsibiity, yakni perasaan tanggungjawab karyawan dalam melaksanakan tugas organisasi yang diemban, karena mereka terlibat didalam proses yang sedang berjalan, dan

3. Reward, yakni penghargaan dan pengakuan atas kerja yang baik sehingga memicu pegawai untuk terus meningkatkan kinerjanya.

Berdasarkan hasil temuan penelitin dan teori terkait tersebut diatas, peneliti menyimpulkan bahwa tidak ada penyimpangan antara praktek dan teori. Dimana hasil penelitian ini menggambarkan secara secara jelas kondisi yang sebenarya.

\section{E. KESIMPULAN DAN SARAN}

\section{Kesimpulan}

Berdasarkan haasil penelitian dan pembahasan maka dapat disimpulkan sebagai berikut :

Tingkat kompetesi pegawai Universitas Methodist Indonesia Medan adalah mayoritas baik dan berpengaruh terhadap kinerja pegawai. Sehingga kompetensi pegawai Universitas Methodist Indonesia dinilai masih relevan dengan visi Universitas.

Kondisi iklim organisasi Universitas Methodist Indonesia Medan adalah mayoritas baik dan berpengaruh terhadap kinerja pegawai. Hal ini mengindikasika bahwa institusi mampu membangun iklim organisasi yang kondusif guna mewujudkan tata kelola yang efektif.

Kompetensidan iklim organisasi memiliki pengaruh signifikan terhadap kinerja pegawai, dimana mayoritas kinerja adalah baik. Hal ini mengindikasikan secara keseluruhan bahwa Institusi akan mampu mewjudkan visi dan misi Universitas.

\section{Saran}

Mengingat faktor kompetensi daan iklim organisasi dalam meningkatkan kinerja pegawai, maka dengan ini disarankan :

Kepada Universitas Methodist Indonesia Medan, disarankan untuuk lebih meningkatkan kompetensi pegawai khususnya ketrampilan bai melalui seminar, kursus, dan pelatihan terkait untuk menungkatkan kenerja pegawai, sebab dalam dunia kerja sehari-hari kompetensi ketrmpilan lebih diutamakan daripada kompetensi pengetahuan. 
Disarankan agar iklim organisasi kerja dapat lebih diperbaiki seperti halnya peningkatann motivasi dan disiplin kerja. Hal ini sesuai dengan hasil analisis quadrant, dimana kondisi ikim organisasi UMI Medan paling relevan dengan quadrant I yang menekankan pentingnya peningkatan motivasi untuk lebih meningkatkan kinerja pegawai.

\section{DAFTAR PUSTAKA}

Ackerman, P. L., 1998. Components of Individual Differences During Skill Acquisition Cognitive Abilities and Information Processing., Journal of Experimental Psychology.

Ainsworth M, Smith M, Millership A. 2007. Managing Performance Managing People. Jakarta: Terjemahan, PT. Bhuanna Ilmu Komputer.

Arikunto, (2003). Prosedur Penelitian Suatu Pendekatan Praktik. Jakarta. Edisi Revisi IV, Rineka Cipta.

Bungin Burhan. (2008). Metodologi Penelitian Kuantitatif: Komunikasi, Ekonomi, dan Kebijakan Publik sera Ilmu-Ilmu Sosial lainnya. Jakarta. Kencana Prenada Media Group.

Davis, Keith, 2000, Perilaku Organisasi, Jilid I, Edisi ke tujuh (Alih Bahasa Agus Dharma), Erlangga: Jakarta.

Dharma, Surya., 2005, Manajemen Kinerja, Cetakan Pertama, Yogyakarya, Pustaka Pelajar.

Effendy, 2006: Pengaruh Kompetensi terhadap Kinerja Karyawan Kantor Pelayanan Pajak Metro (Studi Kasus pada Kantor Pelayanan Pajak Metro,
Program Magister Manajemen

Fakultas Ekonomi Universitas Lampung.

Eko Budi Risetiawan, 2002. Pengaruh Iklim

Organisasi dan Motivasi terhadap

Kinerja Karyawan Perusahaan

Daerah Air Minum Kabupaten Blora

Program Pascasarjana Universitas

Lampung.

Ellis, C, W, 2005, Manajemen Skill for New

Manager, American Management Assosiation.

Fitriyadi, 2001, Pengaruh Kompetensi Skill,

Knowledge Ability dalam

Pengembangan Sumber Daya

Manusia terhadap Kinerja Operator

PD. Bangun Banua Provinsi

Kalimantan Selatan. Program

Pascasarjna Universitas Hasanuddin.

Gibson J. L., Ivancevich J. M. and J. H.

Donnelly, 2003, Organisasi:

Perilaku, Struktur, dan Proses.

Terjemahan. Erlangga, Jakarta.

Glick., 2004, Performance, Volitional

Absence, and Voluntary Turn Over,

Academy of Management Journal 29(3): 441-464.

Haryadi, 2005. Faktor-Faktor yang

Mempengaruhi Kinerja Dosen dan

Hasil Belajar Mahasiswa Universitas

Jendral Sudirman. Disertasi.

Bandung. Universitas Pendidikan Idonesia.

Hasibuan, Melau S. P. 2001. Manajemen

Sumber Daya Manusia. Jakarta. Bumi Aksara.

-(2003). Organisasi \& Motivasi Dasar 
Peningkatan Produktivitas. Jakarta. Bumi Aksara.

Hersey \& Blanchard. 1995. Manajemen

Perilaku Organisasi: Pendayagunaan Sumber Daya Manusia

(Terjemahan). Jakarta. Erlangga.

Himatul. A, 2008. Pengembangan Kinerja

Dosen, Studi tentang Kontribusi Perilaku Kepemimpinan, Iklim Organisasi, dan Motivasi Berprestasi terhadap Kinerja Dosen di Universitas Muhammadiyah Surakarta. Disertasi. UPI Bandung. Tidak Diterbitkan.

Hutapea, 2008 Parulian dan Nurianna

Thoha. 2008. Kompetensi Plus. Jakarta: PT. Gramedia Pustaka Utama.

Ilyas, Y, 2001, Kinerja: Teori, Penilaian dan

Penelitian, Fakultas Kesehatan Masyarakat Universitas Indonesia, Jakarta.

Lawler and Porter M. E., 2001, Keunggulan Bersaing: Menciptakan dan Mempertahankan Kinerja Unggul. Terjemahan. Binarupa Aksara, Jakarta.

Lee, T. W., Mitchell, T. R., Sablynski, C. J., Buthon, 2001, The Effect of Job Embededness on Organizational Citizenship.

Luthans, 2002, Performance and

Motivation, Prentice Hall, New York.

Maria Susila, 2004. Pengaruh Kompetensi

Professional dan Iklim organisasi terhadap Kinerja Dosen. (Studi Kasus pada Akademi Keperawatan Watan Budi Luhur dan Ahmad Yani Cimahi). Tesis. Bandung. UPI.
Mathis R.L. dan Jackson J.H., 2002, Manajemen Sumber Daya Manusia, Salemba Empat, Jakarta.

Milton Fogg, 2004. The Greatest Networker in Tehe World, The Three Rivers Press, New York.

Muchlas, M., 1998, Perilaku Organisasi, Gadjah Mada Press, Yogykarta.

Murlis, A., 2004, Manajemen Reward. Gramedia, Jakarta.

Notoatmodjo, S., 2003, Pengembangan Sumber Daya Manusia. Edisi Revisi, Rineka Cipta, Jakarta.

Parluhutan, 2009, Pengaruh Kompetensi terhadap Kinerja Petugas Promosi Kesehatan Puskesman di Wilayah Kerja Dinas Kesehatan Kota Pematangsiantar Program Pascasarjana Universitas Sumatera Utara.

Prihadi, S., 2004, Kinerja, Aspek Pengukuran, Gramedia, Jakarta.

Prayitno, Widodo dan Suprapto, 2002. Standarisasi Kompetensi Pegawi Negeri Sipil Meuju Era Globalisasi Global. Seri Kertas Kerja Volume II Nomor 05, Pusat Penelitian dan Pengembangan BKN, Jakarta.

Rivai, Veithzal, 2004, Sistem yang Tepat Untuk Menilai Kinerja Karyawan dan Meningkatkan Daya Saing Perusahaan, Penerbit PT. Raja Grafindo Persada, Jakarta.

Robbins, S.P., 2007, Organizational Behaviour Sevent Edition, Prentice Hall Internatioal, Inc.

Spencer, Lyle M. Jr. \& Spencer, Signe M. (1993). Competence at Work, Modelsfor Superior Performance. John Willey \& Soon Inc. 
Sambas, 2008. Pengaruh Kompetensi dan

Iklim Kerja terhadap Kinerja Staf. (Studi Kasus pada Unit Penunjng Medik Rumah Sakit Umum Pusat H. Adam Malik, Medan). Tesis Sekolah Pascasarjana USU Medan.

Stringer, R., 2002, Leadership and

Organizational Climate, Prentice

Hall, New Jersey.

Subanegara, 2004. Head Diamond Drill,

Andi, Yogyakarta.

Sugiyono, 2002, Metode Penelitian

Administratif, Cetakan ke-9

Alfabeta, Bandung.

Suparno. 2001. Membangun Kompetensi

Belajar, Jakarta: Direktorat Jendral

Pendidikan Tinggi Depdiknas.

Suprihanto, John., 2000, Penilaian Kinerja

dan Pengembangan Karyawan,

Yogyakarta, BPFE.

Wibowo, 2007. Manajemen Kinerja. Jakarta.

PT. Raja Grafindo Persada.

Wihardi, 2002. Memotivasi dan

Pemotivasian dalam Manajemen.

Jakarta PT. Raja Grafindo Persada.

Wirawan, 2002. Kapita Selekta Teori

Kepemimpinan Pengantar Untuk

Praktek dan Peneliti Buku 2. Jakarta.

Yayasan Bangun Indonesia \& Umhaka Press.

--------2007. Budaya dan Iklim Organisasi,

Teori Aplikasi dan Penelitian. Jakarta. Salemba Empat.

Undang-Undang R.I. No. 14 Tahun 2004.

Tentang Guru dan Dosen. Bandung.

Citra Umbara.

Undang-Undang R.I. No. 20 Tahun 2003.

Tetang Sistem Pendidikan Nasional. Jakarta. Biro Hukum dan Organisasi
Sekretariat Jenderal Pendidikan

Nasional. 